\title{
Acetanilide herbicide degradation using indigenous soil microorganisms
}

\author{
S. Farooq, I. Hashmi, M. Arshad \& I. A. Qazi \\ Institute of Environmental Sciences and Engineering, \\ School of Civil and Environmental Engineering, \\ National University of Science and Technology, Islamabad, Pakistan
}

\begin{abstract}
A lab scale study was conducted to investigate the degradation of S-Metolachlor $(82.1 \% \mathrm{~W} / \mathrm{W})$ using indigenous soil culture. S-Metolachlor is a pre-emergent acetanilide herbicide for the control of annual grasses and broadleaf weeds. Health advisory level (HAL) of S-Metolachlor by US EPA is $0.525 \mathrm{mg} / \mathrm{L}$ in drinking water. The bacterial culture capable of degrading S-Metolachlor was isolated from soil with the help of an enrichment technique. Isolated bacterial cultures were identified as Pseudomonas sp. by using morphological and biochemical characteristics. Molecular identification of Pseudomonas sp. with the help of Polymerase Chain Reaction (PCR) was also conducted. Pure culture of Pseudomonas aeruginosa (ATCC 27853) was used to determine its degradation capacity. By using incubator an orbital shaker bacterial degradation capacity at 10,20 and $50 \mu \mathrm{g} / \mathrm{ml}$ were determined. Gas chromatography and total organic carbon (TOC) were used to determine the concentration of S-Metolachlor at varied time intervals. TOC of S-Metolachlor was found to be $169.6 \mathrm{ppm}$. Isolated Pseudomonas sp. and standard culture of Pseudomonas aeruginosa (ATCC 27853) showed higher degradation capacity of S-Metolachlor.

Keywords: S-Metolachlor, biodegradation, Pseudomonas sp., acetanilide herbicide, polymerase chain reaction, gas chromatography, enrichment technique.
\end{abstract}




\section{Introduction}

Agriculture is the mainstay of Pakistan's economy as it contributes 21 percent to GDP and employs about 44 percent of the workforce. Weeds have always proved to be one of the main limiting factors in crop production (Avery [1]). Globally it damages $13.2 \%$ of agriculture production or about $\$ 75.6$ billion per year (Oerke et al. [2]). If herbicide use is abandoned damages to the agricultural sector would increase about 500\% Bridges [3, 4]. In 2004 world-wide herbicides accounted for $45.4 \%$ of the pesticide market (Dinham [5]).

But unfortunately after application of pesticides, it disseminate in the environment and this in-turn results into health issues of un-protected agricultural and industrial workers. Pesticide pollution, pests' resistance and accumulation of residues of pesticides in the body of animals and human beings are the common problems faced by today's world.

Chloroacetanilide herbicide, Metolachlor (2-Chloro- $N$-(2-ethyl-6-methylphenyl)- $N$-(1-methoxypropan-2-yl) is a pre-emergent sprayed to control broadleaf and annual grassy weeds in different kinds of crops. Metolachlor has been replaced in 2003 by the S-Metolachlor, composed of $80 \%$ of the isomer S of the Metolachlor. The S-Metolachlor is the most effective and active form of Metolachlor for weed controls (Shaner et al. [6]). This is widely used to control weeds in maize, cotton, and soybean crops between others (Cao et al. [7]). This herbicide poses high toxicity and can be percolated, signifying a potent source of groundwater pollution (Liu et al. [8] and Scribner et al. [9]). In close vicinity to agricultural soils where these herbicides have been applied generally, acetanilide residues and their metabolites are common in aquifers (Stamper and Tuovinen [10]). Though the degradation of Metolachlor in soils is because of microbial activity predominantly (Buggard et al. [11]), little is known about the microorganisms that carry out this process and the mechanisms by which this occurs. Metolachlor is considered to be more persistent and recalcitrant to degradation than the other chloroacetanilide herbicides in soils and water (Stamper and Tuovinen [10]). The basic aim of this study is to isolate SMetolachlor degrading bacteria from the agriculture soil. Results of this study will be very helpful for the bioremediation strategy of this novel compound.

\section{Materials and methods}

\subsection{Chemicals}

Herbicide S-Metolachlor (trade name: Dual Gold) was obtained from Syngenta Crop Production Franchise in Islamabad. FLUKA S-Metolachlor PESTANAL ${ }^{\circledR}$ (33859), analytical standard was used in current study. The relative molecular mass of herbicide is $283.8 \mathrm{~g} \mathrm{~mol}^{-1}$. It's solubility in water at $20^{\circ} \mathrm{C}$ is $500 \mu \mathrm{g} \mathrm{mL}^{-1}$. All other chemicals used in the study were analytical grade reagents. 
Table 1: $\quad$ Physiochemical properties of S-Metolachlor.

\begin{tabular}{|l|l|}
\hline Molecular formula & $\mathrm{C}_{15} \mathrm{H}_{22} \mathrm{ClNO}_{2}$ \\
\hline Molecular weight & $283.46 \mathrm{~g} / \mathrm{mol}$ \\
\hline Colour & Clear straw-colored liquid \\
\hline Melting point & $61.1^{\circ} \mathrm{C}$ \\
\hline Solubility & $530 \mathrm{mg} / \mathrm{L}\left(20^{\circ} \mathrm{C}\right)$ \\
\hline Half-Life & $15-132$ days \\
\hline Boiling Point & $334^{\circ} \mathrm{C}$ \\
\hline
\end{tabular}

\subsection{Sampling}

Sampling was done from cotton field from the Cotton Research Centre Multan. A soil sample was taken from the top $5 \mathrm{~cm}$ of soil. Soil was kept at $4^{\circ} \mathrm{C}$ in polythene bags before bacterial isolation. The soil was regularly sprayed with Dual Gold (S-Metolachlor 82.1\% W/W). The $\mathrm{pH}$ of soil sample was measured. With the help of an X-ray fluorescence analyser qualitative and quantitative elemental analysis of soil was done.

\subsection{Isolation}

Isolation of specie S-Metolachlor degrading specie was done through an enrichment technique. In this technique Minimal Media $\left(0.5 \mathrm{~g}\left(\mathrm{NH}_{4}\right)_{2} \mathrm{HPO}_{4}\right.$; $0.2 \mathrm{~g} \mathrm{MgSO}_{4} .7 \mathrm{H}_{2} \mathrm{O} ; 0.1 \mathrm{~g} \mathrm{~K}_{2} \mathrm{HPO}_{4} ; 0.001 \mathrm{~g} \mathrm{FeSO}_{4} .7 \mathrm{H}_{2} \mathrm{O} ; 0.01 \mathrm{~g} \mathrm{Ca}(\mathrm{NO})_{3}$ in $1 \mathrm{~L}$ distilled water $\mathrm{pH}=6.2$ ) (Hashmi and $\mathrm{Kim}$ [12]) having $6 \mu \mathrm{l} / \mathrm{ml}$ of S-Metolachlor was utilized. A bacterium showing highest level of growth in Minimal Media at $30^{\circ} \mathrm{C}$ was selected for the degradation studies. Potential bacterium was labelled as SF. An isolated strain was cultured on nutrient Agar slants having S-Metolachlor. The strain was kept at $4{ }^{\circ} \mathrm{C}$ and sub-cultured after every 3 months.

\subsection{Identification and characterization of S-Metolachlor degrading bacteria}

Isolated strain SF was then identified through morphological characters, gram staining, biochemical characterization and analysis of $16 \mathrm{~S}$ rDNA. Biochemical characterization was accomplished by using API E20 kit.

DNA from the isolate was extracted with the help of DNA extraction kit (Norgen Biotek Corporation). The 16S rDNA gene was amplified by Polymerase Chain Reaction using universal bacterial primers 27F (AGAGTTTGATCMTGGCTCAG) and 1492R (ACCTTGTTACGACTT) (Lane et al. [13]). PCR reactions were carried out using TE Thermocycler (Extragene). For the amplification, an initial denaturation step of $10 \mathrm{~min}$ at $95^{\circ} \mathrm{C}$ was followed by 40 cycles of amplification consisting of $1 \mathrm{~min}$ at $95^{\circ} \mathrm{C}, 1 \mathrm{~min}$ at $57^{\circ} \mathrm{C}$ and 10 min at $72^{\circ} \mathrm{C}$. Then PCR product and $1 \mathrm{~kb}$ DNA ladder was run on gel electrophoresis. 


\subsection{Degradation studies}

Minimal media having different concentration of S-Metolachlor $(10 \mu 1 / \mathrm{ml}$, $20 \mu 1 / \mathrm{ml}$, and $50 \mu \mathrm{l} / \mathrm{ml}$ ) was used to determine degradation efficiency of isolated bacterium. Three Erlenmeyer flask of $250 \mathrm{ml}$ for each concentration was kept in an incubator shaker at $30^{\circ} \mathrm{C}$ and $150 \mathrm{rpm}$ for 5 days. Control of the study was minimal media having bacterial culture but no carbon source. The sample was taken at $0,24,48,72$, and $96 \mathrm{hr}$. the degradation potential was determined with the help of total organic carbon (TOC) and gas chromatography.

\subsection{Analytical studies}

For total organic carbon $15 \mathrm{ml}$ sample was filtered in a labelled test tube. Test tubes were kept at $4^{\circ} \mathrm{C}$ until analysis take place. For gas chromatography sample was prepared by adding few drops of $3 \% \mathrm{H}_{2} \mathrm{SO}_{4}$ to kill bacteria present in sample. The sample was then kept at $-20^{\circ} \mathrm{C}$ in dark to avoid any photodegradation. For extraction of sample, liquid-liquid extraction technique was used. Methanol: water (80:20 v/v) and sample was added in test-tube and was kept in orbital shaker for 1 hour. S-Metolachlor was determined with gas chromatograph. The injection temperature was $250^{\circ} \mathrm{C}$ and the detector temperature was $280^{\circ} \mathrm{C}$. The program for detecting S-Metolachlor was as follows: initial oven temperature $80^{\circ} \mathrm{C}$ (hold $1 \mathrm{~min}$ ), ramped at $20^{\circ} \mathrm{C} \mathrm{min}{ }^{-1}$ to $230^{\circ} \mathrm{C}$, and then held at $230^{\circ} \mathrm{C}$ for $2.5 \mathrm{~min}$, with a run time of $11 \mathrm{~min}$. Under these conditions the retention times of Metolachlor was $9.45 \mathrm{~min}$. The detection

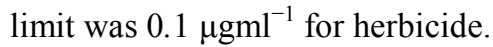

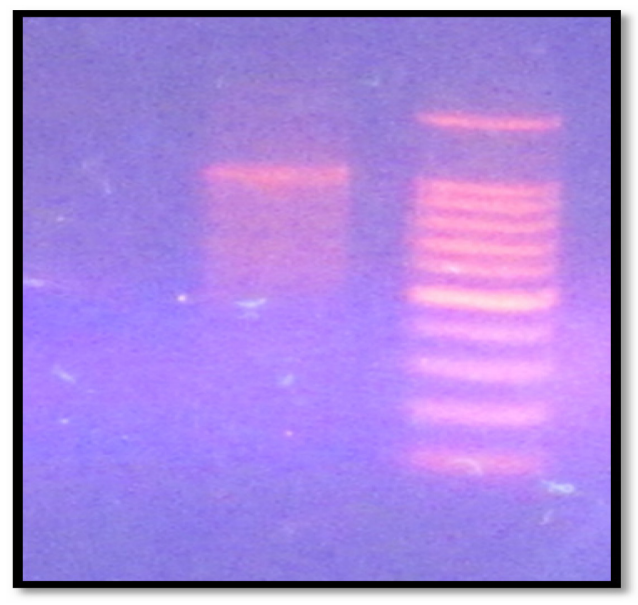

Figure 1: $\quad$ Amplification of 16S DNA genes of (1) Pseudomonas aurignosa on $\mathrm{Tm}=57^{\circ} \mathrm{C}$ run with (2) $100 \mathrm{bp}$ ladder 


\section{Results and discussions}

The $\mathrm{pH}$ of soil was 7.1. Elements present in soil were $\mathrm{Mg}(1.61 \%), \mathrm{Al}(10.99 \%)$ Si (57.74\%), S (0.22\%), K (5.97\%), Ca (3.59\%) Ti $(2.10 \%), \mathrm{V}(0.009 \%), \mathrm{Cr}$ (0.099\%), Mn (0.32\%), Fe (16.93\%), Zn (0.05\%), Sr (0.062\%) and Zr (0.23\%).

Morphological characteristics of isolate SF was irregular shape, undulate margins, off-white colour, smooth and shiny surface. Isolate also release yellowish green characteristic pigment (production of pyocyanin). According to gram staining results isolate was gram negative rods. API kit E20 results predict that the isolated specie was Pseudomonas aeroginosa. Further identification was confirmed through molecular identification. The amplified PCR product was of the 900 base pair which were the characteristics of Pseudomonas aeroginosa.

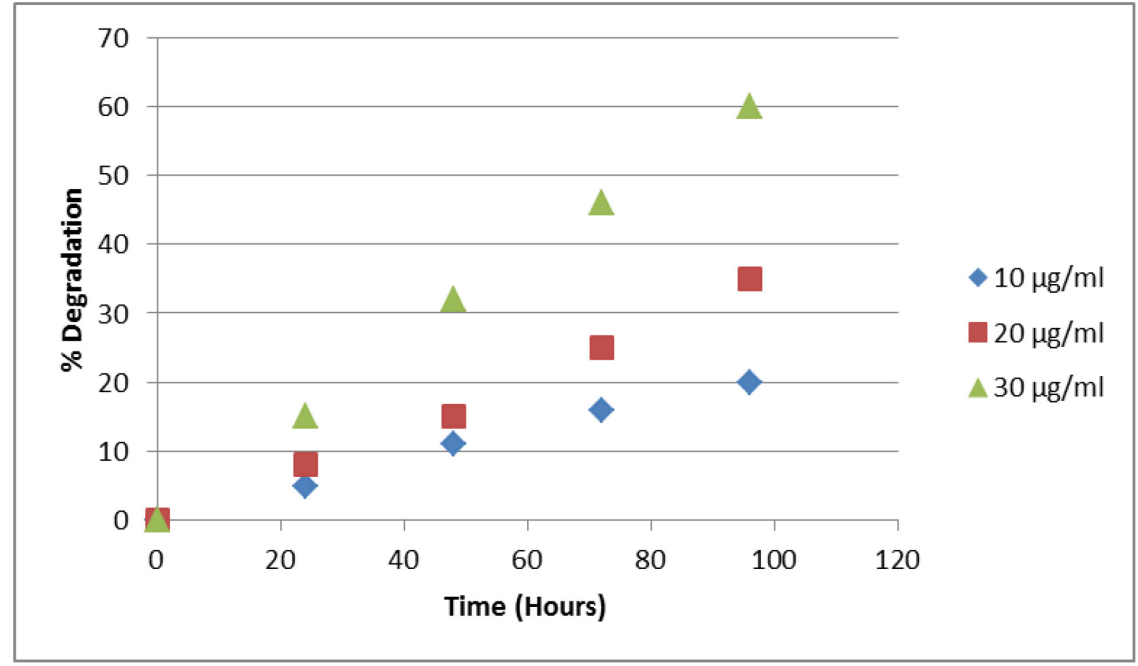

Figure 2: Graph showing \% degradation at different time intervals.

A wide range of carbon sources can be utilized as Pseudomonads are characterised by great metabolic diversity. Pseudomonas sp. that was isolated from soil had degraded $70.7 \%$ Metolachlor in 20 days as reported by Sanayal and Kulshrestha [14]. Biodegradation has been depicted to be the primary mechanism of metolachlor dissipation in soil (Frank et al. [15]).

Results of total organic carbon and gas chromatography depict a significant reduction of S-Metolachlor at a concentration of $50 \mu \mathrm{g} / \mathrm{ml}$ within $96 \mathrm{hrs}$. Degradation efficiency of isolated Pseudomonas aeroginosa makes it promising bacteria for bioremediation.

\section{References}

[1] Avery D.T., Saving the Planet with Pesticides, Biotechnology, and European Farm Reform. Proc. Brighton Crop Prot. Conf. - Weeds, 1, pp. 3-18, 1997. 
[2] Oerke, E.C., H.W. Dehne, F. Schnbeck, and A. Weber. Crop Production and Crop Protection: Estimated Losses in Major Food and Cash Crops, Amsterdam: Elsevier. 1994.

[3] Bridges, D.C. Crop Losses Due to Weeds in the United States. Weed Science Society of America, Champaign, II. pp. 403, 1992.

[4] Bridges, D.C. Impact of Weeds on Human Endeavours. Weed Technology. 8: 392-395. 1994.

[5] Dinham, B. Agrochemical Markets Soar - Pest Pressures or Corporate Design? www.pan-uk.org/pestnews/pn68/pn68p9.htm. 2005.

[6] Shaner, D. L., Brunk, G., Belles, D. Westra, P. and Nissen, S. Soil dissipation and biological activity of Metolachlor and S-metolachlor in five soils. Pest Management Sciences, 62, pp. 617-623, 2006.

[7] Cao P, Wang X, Liu F, Zhao E, Han L Dissipation and Residue of Smetolachlor in Maize and soil. Bulletin of environmental contamination and toxicology 80, 391-394, 2008.

[8] Liu, W.P., Liu, H.J., Zheng, W., Lu, J.H. Adsorption of chloroacetanilide herbicides on soil (I). Structural influence of chloroacetanilide herbicide for their adsorption on soils its components. Journal of Environmental Sciences, 13(1), pp. 37-45,2001.

[9] Scribner E. A., Battaglin W. A., Goolsby D. A., Thurman E. M. Changes in herbicide concentrations in Midwestern streams in relation to changes in use, 1989-1998. Science of the Total Environment, 248(2-3), pp. 255-263, 2000.

[10] Stamper, D. M.; Tuovinen, O. H. Biodegradation of the acetanilide herbicides alachlor, metolachlor, and propachlor. Critical Review in Microbiology, 24, pp. 1-22, 1998.

[11] Buggard, D. J., W. C. Koskinen, R. H. Dowdy, and H. Cheng. Metolachlor distribution in a sandy soil under irrigated potato production. Weed Science. 41, pp. 648-655, 1993.

[12] Hashmi, I. and Kim, J.G. Comparison of degradation studies in a biosimulator by continuous cultivation of Pseudomonas and indigenous micro-organisms with varied dissolved oxygen concentrations. International Journal of Environment and Pollution, 19(2), pp. 123-138, 2003.

[13] Lane, D.J. 16S/23S rRNA sequencing. In: Nucleic acid techniques in bacterial systematics. Stackebrandt, E., and Goodfellow, M., eds., John Wiley and Sons, New York, New York, pp. 115-175, 1991.

[14] Sanayal, D. and Kulshrestha, G. isolation and characterization of Metolachlor Degrading Bacteria. Pesticide Research Journal, 15(1), pp. 85-89, 2003.

[15] Frank, R., Clegg, B. S., Patani, N.K. Dissipation of cyanaazine and metolachlor on a clay loam soil Ontario Canada, 1987-1990. Archives of Environmental contamination and toxicology, 21, pp. 253-262, 1991. 